\title{
Non-Invasive Prenatal Testing (NIPT) for Low-Risk Women
}

\section{Schulze B ${ }^{1}$, Ganeshananthan $S^{1}$,}

Screening, and definitive diagnosis, of chromosomal abnormalities is an important part of obstetric care, fraught with emotional decisions and controversy. With technological advancements, new modalities for screening and diagnosis are being developed, which inherently produce a multitude of associated contentious issues. It is the obstetrician's duty to inform patients of their options for prenatal testing which are ever increasing in diversity with advanced research and technological improvements. Therefore, it is imperative for practitioners to remain informed about available options, as well as the potential associated controversies. Obtaining genetic material for analysis of fetal genetics was previously only possible via invasive procedures (CVS to obtain mesodermal connective tissue and placental trophoblast cells or amniocentesis to obtain amniotic fluid samples of mostly epithelial origin), with increased maternal and fetal risks (mainly miscarriage and infection).

However, after discovery of cell-free fetal DNA (cffDNA) in maternal serum in 1997, extensive research has led to the development of non-invasive prenatal testing (NIPT) for fetal aneuploidy screening 1 . Fetal DNA circulates in maternal blood in two forms, either as intact fetal cells or circulating cffDNA from the breakdown of mainly placental cells. Whilst "intact fetal cells can persist for years after a pregnancy, cell-free DNA clears from the maternal system quickly and is undetectable in maternal serum within hours of delivery ${ }^{1,2}$. Thus cffDNA detected during a pregnancy is DNA considered to be representative of the current fetus. At present, NIPT is recommended solely for high-risk populations (i.e. advanced maternal age, abnormal serum screen, abnormal ultrasound, personal/family history of aneuploidy). However, there is interest surrounding whether the same validation data can be found to support testing in all populations, due to inconclusive data which is not currently supported by professional associations ${ }^{3}$.

A recent paper by Bianchi et al has received attention regarding NIPT use for average risk populations ${ }^{4}$. Supported by a commercial laboratory, the authors compared NIPT with traditional aneuploidy screening on a relatively small number of average risk women, introducing potentials for bias into the trial. According to the Society for Maternal and Fetal Medicine this "study

${ }^{1}$ Logan Hospital Cnr Armstrong Road \& Loganlea Road, Meadowbrook QLD 4131, Australia

\section{Correspondence:}

Dr. Sabaratnam Ganeshananthan

Email: ganeshananthan@gmail.com

Competing interests: None was too small to compare detection rates, but the authors report that the false positive rate of NIPT is lower and therefore the test 'merits serious consideration as a primary screening method for fetal autosomal aneuploidy.'"5 Additionally, many samples were obtained in the third trimester-when aneuploidy screening is not clinically relevant and fetal DNA assays are higher, which may account for improved test results ${ }^{4}$.

NIPT analyses cffDNA via a peripheral sample as early as ten weeks (typically between 10-22 weeks), but is still deemed to be a screening test ${ }^{2}$. Commercial laboratories employ differing methodologies for testing; however, "the overall reported performance is similar, with detection rates for Down syndrome above $99 \%$ and false positive rates that are $<1 \%$." Subsequently, women with positive results will require counselling regarding their individual risk, in order to discuss appropriate diagnostic testing to determine fetal DNA composition definitively ${ }^{6}$. As demonstrated in the most recent CARE study in the New England Journal of Medicine, "using NIPT rather than conventional aneuploidy screening could potentially result in an $89 \%$ reduction in diagnostic procedures necessary to confirm a positive screen result." This will inherently reduce unnecessary invasive tests and hopefully diminish associated parental anxiety and stress. This study also has shown that NIPT "performs consistently well in all pregnant women, regardless of the a priori risk for fetal aneuploidy" 4 .

Sensitivity and specificity of NIPT is quoted at $99.9 \%$; however, PPV and NPV will change depending upon background population risk. Therefore, if a woman in a high risk population has a prevalence of trisomy 21 of $5 \%$, there will be a quoted risk of $1 / 20$, her PPV is very high $(4995 / 5000) \sim 98 \% 7$. Conversely, a woman in a low risk population (prevalence $0.1 \%$ ), even with the same test sensitivity and specificity will have a much lower PPV of approximately $50 \%(100 / 200)$, which are crucial messages to explain to patients (table) $)^{7}$. Furthermore, the fetal fraction must be high enough to obtain an adequate sample, which can be influenced by maternal factors, especially obesity. Statistics for failure to obtain results range from 1-12\%, which must be highlighted to patients, especially if in these certain demographic populations known to have increased risk of failure ${ }^{6}$. The conclusions proposed by Bianchi et al require extensive further investigation and data collection/analysis, with many study limitations mainly being "underpowered to compare the detection rates and it is generally not valid to compare false-positive rates in isolation." ${ }^{4}$ Additionally, false positive rates were only analysed for trisomies 18 and 21, without mention of trisomy 13 and sex chromosomes, which are also tested by commercial laboratories (with higher false positive rates $)^{8-10}$. 
Extensive counselling pre-and-post-testing is imperative for management of difficult situations. Currently, NIPT is not indicated for twins; however, some laboratories are starting to analyse this data if women meet a strict inclusion criteria with similar risk factors of those with singleton pregnancies ${ }^{11}$. Furthermore, sex aneuploidies are also now able to be screened with advanced technology by some companies; however, not all chromosomal anomalies (i.e. unbalanced translocations, deletions and duplications) will be detected. False-positive results can still occur; therefore, confirmatory invasive testing with CVS or amniocentesis is still recommended ${ }^{12}$. Patients must also be aware of false negative results, which cannot ensure an unaffected pregnancy. The benefits and impact of NIPT in rural communities have not been thoroughly researched; however, it is evident that travel and interruption to lifestyle are major factors to consider for these families when diagnostic testing is required. Furthermore, the extended "shelf-life" of these NIPT samples, which currently requires international testing, is an additional benefit for families in rural and remote communities, where potential logistical problems may arise due to geographical isolation ${ }^{8-10}$.

Another aspect fraught with controversy is the associated cost of testing. As technology develops, there is likely to be a reduction in out-of -pocket expense to patients. Presently, the cost for testing in Australia varies from \$495-1000, depending upon the laboratory, which usually includes genetic counselling. Some insurance companies will partially subsidise this cost for women at risk. Yet with popularity and maternal age increasing, and women requesting 'reassurance' (with low-risk first CFTS or who do not meet testing criteria), there is an increased financial burden which must be considered. Nevertheless, in many circumstances, the reassurance and/or diagnosis received allows for definitive decisions, timing and planning to be made about the pregnancy which, for many couples, is priceless. Practitioners must broach the predicament of patient autonomy versus appropriate resource use with caution and supporting evidence.

RCOG concludes that "in time, this technology is likely to become the primary screen for chromosomal abnormalities in pregnancy." ${ }^{13}$. ACOG recommends that all women, regardless of age, be offered prenatal assessment for aneuploidy, either by screening or invasive diagnosis, including NIPT ${ }^{12}$. Therefore, there is still a considerable amount of controversy surrounding prenatal testing, which with time and technology will continue to unfold.

\section{References}

1. Gil MM, Akolekar R, Quezada MS, Bregant B, Nicolaides KH. Analysis of cell-free DNA in maternal blood in screening for aneuploidies: meta-analysis. Fetal Diagn Ther 2014; 35: 156-173.

2. Lo YMD, Corbetta N, Chamberlain PF, Rai V, Sargent IL, Redman CW, Wainscoat JS.. Presence of fetal DNA in maternal plasma and serum. Lancet 1997;350:485-7.

3. Chiu RW, Akolekar R, Zheng YW, Leung TY, Sun H, Chan KC, Lun FM, Go AT, Lau ET, To WW, Leung WC, Tang RY, Au-Yeung SK, Lam H, Kung YY, Zhang X, van Vugt JM, Minekawa R, Tang MH, Wang J, Oudejans CB, Lau TK, Nicolaides KH, Lo YM. Non-invasive prenatal assessment of trisomy 21 by multiplexed maternal plasma DNA sequencing: large scale validity study. BMJ. 2011 Jan 11;342:c7401. doi: 10.1136/bmj.c7401

4. Bianchi DW, Parker RL, Wentworth J, Madankumar R, Saffer C, Das AF, Craig JA, Chudova DI, Devers PL, Jones KW, Oliver $\mathrm{K}$, Rava RP, Sehnert AJ; CARE Study Group. DNA sequencing versus standard prenatal aneuploidy screening. N Engl J Med. 2014 Feb 27;370(9):799-808. doi: 10.1056/NEJMoa1311037.

5. Society for Maternal Fetal Medicine. "SMFM Statement: Maternal serum cell-free DNA screening in low risk women." Available from: https://www.smfm.org/publications/157-smfm-statementmaternal-serum-cell-free-dna-screening-in-low-risk-women

6. Caramins M, Chopra M. Non-Invasive Prenatal Testing, Common Sense Pathology Feb 2014. https://www.rcpa.edu.au/ getattachment/32b2d61c-2669-467e-afdf-8f1476444304/Noninvasive-Prenatal-Testing.aspx

7. Sekizawa A, Purwosunu $Y$, Matsuoka R, Koide K, Okazaki S, Farina $A$, Saito $H$, Okai T. Recent advances in non-invasive prenatal DNA diagnosis through analysis of maternal blood. $\mathrm{J}$ Obstet Gynaecol Res. 2007 Dec;33(6):747-64

8. Benn, $P$ et al. "ISPD Rapid Response Statement. Prenatal detection of Down Syndrome using Massively Parallel Sequencing (MPS): a rapid response statement from a committee on behalf of the Board of the International Society for Prenatal Diagnosis."

\begin{tabular}{|c|c|l|l|l|c|}
\hline \multicolumn{7}{|c|}{$\begin{array}{r}\text { Table1 : Detection rates of common chromosomal } \\
\text { aneuploidies by NIPT }\end{array}$} \\
\hline & N & Sensitivity & $95 \%$ Cl & Specificity & $95 \%$ Cl \\
\hline Trisomy 21 & 500 & $>99.9 \%(90 / 90)$ & $96-100.0$ & $99.8 \%(409 / 410)$ & $98.7-100.0$ \\
\hline Trisomy 18 & 501 & $97.4 \%(37 / 38)$ & $86.2-99.9$ & $99.6 \%(461 / 463)$ & $98.5-100.0$ \\
\hline Trisomy 13 & 501 & $87.5 \%(14 / 16)$ & $61.7-98.5$ & $>99.9 \%(485 / 485)$ & $99.2-100.0$ \\
\hline
\end{tabular}


October 24, 2011. Available from: http://www.ispdhome.org/ public/news/2011/ISPD_RapidResponse_MPS_240ct11.pdf

9. Verifi (C) Prenatal Test. Verinata Health Inc. (C) 2012. Analytical Validation of the Verifi (C) Prenatal Test: Enhanced Test Performance For Detecting Trisomies 21, 18 and 13 and the Option for Classification of Sex Chromosome Status. Available from: http://www.verifitest.com/healthcare-professionals/http:// www.verifitest.com/journal/Spring-2014/care-just-the-facts/ http://www.verifitest.com/journal/Spring-2014/nipt-just-for-highrisk-reimbursement-considerations-for-the-general-obstetricalpopulation/; $\quad$ http://www.verifitest.com/journal/Spring-2014/ statistics-101-revisiting-the-basics/

10. Lewis, R. Medscape Medical News. "Fetal DNA Testing for Low Risk Women gets Mixed Reviews." (c) March 8, 2014. Available from: http://www.medscape.com/viewarticle/821690
11. The American College of Obstetricians and Gynaecologists Committee on Genetics. The Society for Maternal-Fetal Medicine Publications Committee. "Noninvasive Prenatal Testing for Fetal Aneuploidy." Committee Opinion. No. 545. Obstet Gynecol 2012; 120:1532-4.

12. American College of Obstetricians and Gynecologists. ACOG Screening Guidelines in Chromosomal Abnormalities. (C) May 7, 2007. Available from: http://www.acog.org/About_ACOG/News_ Room/News_Releases/2007/ACOGs_Screening_Guidelines_ on_Chromosomal_Abnormalities

13. Non-invasive Prenatal Testing for Chromosomal Abnormality using Maternal Plasma DNA. Scientific Impact Paper No. 15, RCOG 2014 